\section{Espaços Livres Públicos O Caso das Praças do Metrô de São Paulo}

\author{
Vladimir Bartalini
}

Resumo

Estudo sobre o papel dos espaços públicos centrais nas correntes urbanisticas, desde o fim do século XIX e suas atuais possibilidades.

A praça pública ocupou um lugar de destaque no chamado urbanismo culturalista, perdendo sua importåncia, enquanto expressão de centralidade, a partir do urbanismo racionalista. Com ênfase nas questōes de projeto, destacam-se os trabalhos de Sitte (1898), que define parâmetros de projetação; e de Zucker (1959), que chega a identificar os arquétipos espaciais das praças. As propostas contidas nestes trabalhos estão limitadas em sua realização prática, por partirem do pressuposto da unidade indissolúvel entre o espaço da praça e os ediffcios que a conformam. Na ausência destas condiçōes, os espaços livres, carentes de significado formal, não são considerados praças, ou são classificados como "praças amorfas", segundo Zucker. Nesta categoria estaria inclufda a grande maioria das praças existentes e projetadas, dadas as raras oportunidades que se oferecem hoje para um projeto idealmente integrado. A superação deste impasse pode ser conseguida em projetos que assumam as condiçōes da realidade espacial do lugar em que se inserem, buscando a um só tempo uma consistência arquitetônica própria e a abertura para a descontrolada paisagem circundante. This article is taken from a paper which discusses the aims and perfomance of open public spaces around subway stations in São Paulo.

It emphasizes the role of the public squares in urbanism from the end of 19 th century to nowadays.

It deals with the specific questions about open space design discussing the aesthetic considerations expressed by Camillo Sitte (1898) and Paul Zucker (1959) on this subject, and secarching for new criteria for public squares design.
Professor Assistente MS-2, alocado no Grupo de Disciplina Palsagem e Amblente do Departamento de Projetos da Faculdade de Arquitetura e Urbanismo - USP (em afastamento).

Dissertaçåo de Mestrado "Praças do Metro: Enredo, Produçáo, Cenário, Atores". Jun. 1988. Orlentador: Profa. Dra. Miranda Martinelli Magnoll. 
É de chamar a atençăo a quantidade de logradouros públicos cadastrados como "praças" e destituldos de significados espaciais compativeis com esta denominaçăo.

Impressiona também a atual fragilidade destes espaços que já foram elementos de primeira grandeza no pensamento urbanlstico. Em nossas cidades "praças" săo construf das com a mesma facilidade com que são destrufdas, o que vem atestar o nivel de banalizaçăo a que foram reduzidos estes elementos.

Tomemos como exemplo a implantação das linhas norte-sul e leste-oeste do Metrô de Såo Paulo que, dentre as intervençőes urbanas mais recentes foi uma das que acarretou maiores transformaçōes nos espaços por ela afetados.

Uma das peculiaridades do Metrô de São Paulo, em suas implicaçð̋es com a paisagem urbana, é a freqũente associação de suas estaçōes com espaços livres públicos genericamente denominados "praças".

A implantação das estaçōes deu oportunidade ao surgimento de novas praças públicas e também ao desaparecimento ou tranformaçăo das já existentes.

As razőes da ocorrência do binômio praça-estação podem ser buscadas, em alguns casos, na facilidade e economia decorrentes da implantação das estaçōes em áreas públicas já existentes; em outros casos pode-se perceber intuito urbanistico e de promoçåo da imagem da Companhia do Metrô; e houve também sobras de áreas que viraram "praças" por não se prestarem a nenhum outro fim.

Em qualquer circunstância, mesmo quando houve intenção de se criar praças significativas e recursos suficientes para tanto, os resultados ficaram em geral muito distantes dos padrōes que consagraram as praças, no passado, como espaços privilegiados por seu papel simbólico, por sua efetiva utilizaçảo, por sua concepçảo urbanistica e arquiteto̊nica.

A decadência constatada não pode ser simplesmente imputada a este ou àquele órgão público. Ela é sobretudo resultado dos processos que vêm alterando a forma de vida urbana e o próprio conceito de cidade.

As mudanças que vêm se processando acabam por conduzir o modo de vida urbano a outras direções alterando o significado de seus espaços e propondo outras formas de expressão de centralidade que não a praça. Henri Lefébvre aponta o centro de decisão como a forma de centralidade típica de neocapitalismo, centralidade que pode dispensar o urbano por completo, como forma e como conteúdo. Juergen Habermas pergunta se o próprio conceito de cidade não está ultrapassado.

Apesar disto subsistem certos lugares em que o caråter urbano sobrevive, mesmo não sendo mais uma forma hegemónica. E assim como o conteúdo urbano perdura em certos espaços, a despeito das forças contrárias, também perśistem algumas formas que o expressaram com propriedade. Até que ponto são formas anacrônicas?

De certo as praças não são mais, nem poderiam ser, a referência da cidade como um todo, mas podem perfeitamente ser referência espacial e simbólica para muitos bairros ou setores da cidade e acolher parte significativa da vida cotidiana. Mas para isto é preciso haver o minimo de intencionalidade de modo a que venham a ser mais do que meros subprodutos de intervençōes urbanas, sobras de áreas às quais se aplica um tratamento superficial qualquer.

Portanto, parece-nos oportuno trazer à tona algumas reflexões sobre 0 assunto.

As condições para a realização de praças públicas são hoje, em todos os sentidos, muito diversas das do passado. Interessa-nos aqui abordar especificamente os aspectos referentes às propostas urbanisticas, às caracterlsticas de localização e de forma que afetam os projetos destes espaços, iniciando por um apanhado geral das concepç̋̄es referentes ao tema desde o final do século XIX e terminando pela análise de um projeto de elaboração e execução recentes - a praça da estação de Sants, em Barcelona - que, diante de condiçōes bastantes desfavoráveis e ao mesmo tempo comuns nas cidades de hoje, dá respostas que contribuem para renovar a discussão sobre o projeto de espaços livres públicos em áreas centrais. 
O espaço livre público central, mais especificamente a praça, já desempenhou um papel fortemente simbólico através de seus ancestrais - a ágora e o fórum - foi o foco da vida cotidiana e da Festa na Europa Medieval e tornou-se objeto privilegiado da "arte urbana" no barroco. Que papel foi reservado a este tipo de espaço público pelo pensamento urbanistico, quando os efeitos da industrialização incidiram sobre a cidade desfazendo antigas conformaçōes, propondo novas questōes ou mesmo ameaçando o urbano (valor de uso) de desaparecimento?

Camillo Sitte, expoente do chamado urbanismo culturalista ${ }^{1}$ do fim do século XIX, procura em suas propostas recriar a atmosfera das cidades antigas enquanto lugares de concentração, movimento, realizaçōes de múltiplas atividades, e busca recuperar o sentimento de pertinência do cidadăo à sua cidade. $O$ cenário próprio para o desenrolar de uma vida urbana como a idealizada por Sitte é buscado nos modelos do passado, pelo estudo da escala dos antigos espaços públicos, seu modo de inserção na malha urbana, reproduzindo a densidade espacial que sempre caracterizou os centros das cidades. Elege as praças e as ruas como formas diretoras do traçado urbano e como locais para a vida pública e para os espetáculos. Preconiza sua localização centralizada, reunindo os ediffcios principais, enquanto os espaços verdes seriam distribuldos de modo homoge̊neo e afastados dos lugares mais movimentados. Rejeita a regularidade, a simetria (entendida como a semelhança de imagens em relação a um eixo principal), o apelo irrefletido à geometria. Valoriza as particularidades do lugar, explora as irregularidades, confere à cada praça um caráter próprio e único. Na obra "O planejamento das cidades de acordo com os princlpios artlsticos", publicada em 1889, Sitte expõe suas recomendaçōes para o projeto de praças, aprofundando-as ao nivel das formas, dimensōes e proporçōes, relaçōes com os ediffcios, monumentos e ruas circundantes. A praça deve ser um recinto fechado pela continuidade dos ediffcios dispostos a sua volta e as ruas devem desembocar na praça de modo a não destruir este fechamento: "Hoje é norma fazer duas ruas se interceptarem em ångulo reto em cada canto de uma praça pública, provavelmente para abrir seus cantos e assim isolar o mais possivel os blocos de ediffcios entre si, impedindo qualquer efeito de continuidade e coerência. Justamente o contrário era feito no passado: se possivel apenas uma rua desembocava em cada ponto; as bifurcaçōes ocorriam fora do campo visual da praça". Sobre as dimensōes das praças observa: "Uma praça muito pequena năo dá o devido efeito aos ediffcios monumentais; por outro lado, uma praça muito grande é, certamente ainda pior pois mesmo os maiores ediffcios parecem pequenos em relação a ela ... . De 190 a 470 pés (aproximadamente 63 a $155 \mathrm{~m}$ ) é a dimensão média das maiores praças nas velhas cidades. De modo geral, quanto maior o espaço menor é o efeito dos seus ediffcios e monumentos ....".

Raymond Unwin, o construtor da primeira cidade jardim, baseou-se nos preceitos de Sitte para o projeto do núcleo central de Letchworth, embora tenha adotado algumas soluçōes (por exemplo, avenidas largas para comunicar praças entre si) que talvez não recebessem a aprovação do mestre. Entendia, ao contrário de Sitte, que a regularidade poderia produzir beleza: “... nāo podemos deduzir ... que a regularidade não vá produzir beleza, nem que seja antinatural para o homem realizar seu trabalho segundo traçados regulares". No livro "A prática do urbanismo - uma introdução à arte de projetar cidades e bairros" publicada pela primeira vez em 1909, além de reafirmar as idéias de Sitte, apresenta suas próprias contribuições. Defende a formação de um centro principal e de centros secundários nas cidades a serem projetadas, com suas respectivas praças. Faz também recomendaçōes urbanisticas especfficas sobre as estaçōes de estrada de ferro: “... na frente da estação deve haver um espaço livre ou praça para dar dignidade à entrada principal da cidade e para proporcionar espaço ao fluxo que ele reúne, e no tratamento deste lugar o pedestre deve ser considerado (...). Normalmente o lugar da estação não deve ser a praça central da cidade, mesmo onde a estação de trem fica próxima do verdadeiro centro da cidade, embora neste caso provavelmente a praça central não deva estar muito longe da estação e pode ser a ela conectada por amplas e importantes artérias ou avenidas".

Ebenezer Howard, o idealizador das cidades jardins, ainda, que considerado culturalista pela defesa de limites precisos para as cidades, pela importåncia atribulda à dife-
(1) Françolse Choay distingue dols modelos princlpals de propostas urbanistlcas que se opoem nos pressupostos a nos resultados: O culturallsta e o progressista (também referldo como urbanlsmo raclonallsta). 
Figura 1

Plano de Letchworth - Raymond Unwin.

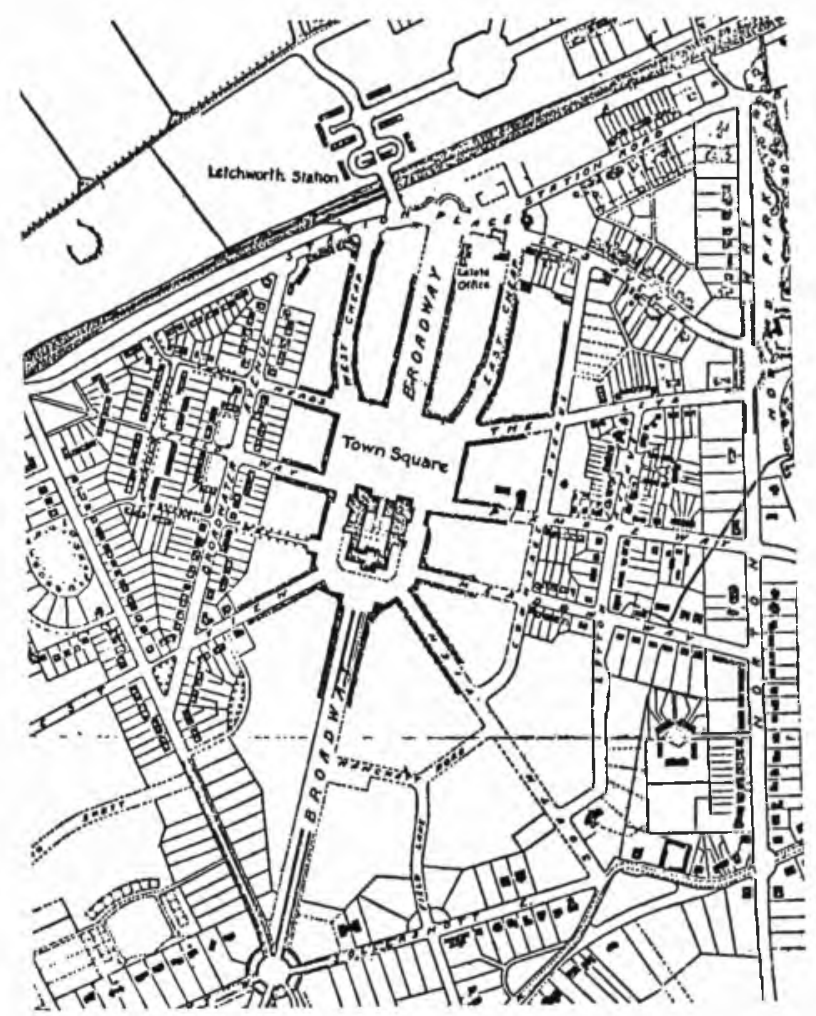

Figura 2

Diagrama da Cidade Jardim.

Ebenezer Howard.

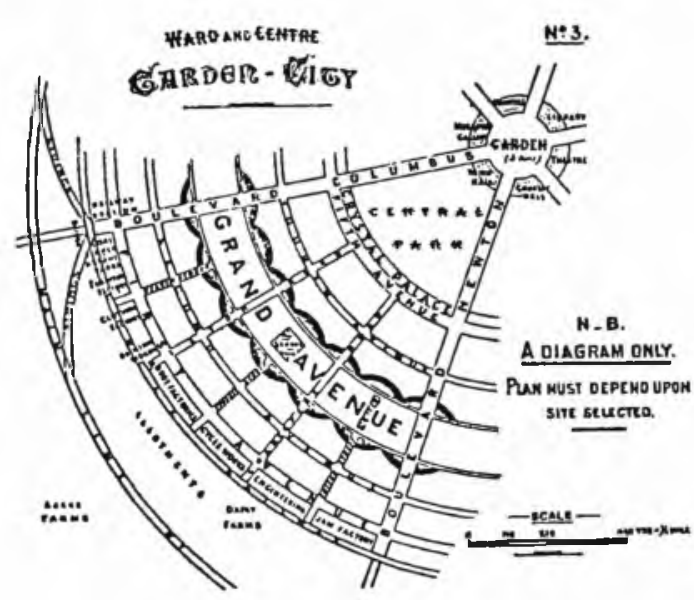

Figura 3

Ville Radieuse - Le Corbusier.

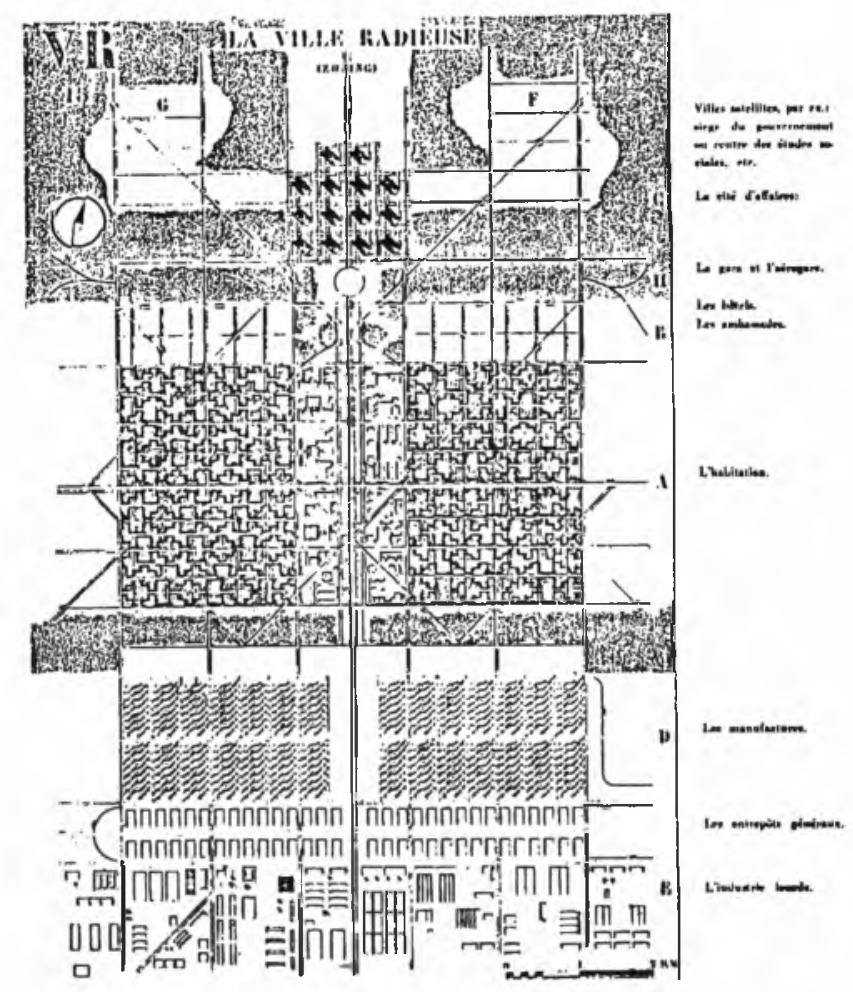


renciação e pela prevalência dos valores culturais e comunitários sobre a noção material de cidade, não se apoiará em modelo do passado. Suas propostas têm uma dimensão utópica que ele se dedica a equacionar prevendo as condiçōes para a compra do terreno para a cidade jardim, do financiamento do empreendimento e do seu gerenciamento futuro. Define o tamanho da população e estabelece as dimensões e a forma esquemática da cidade jardim e das partes que a compõem, particularmente a área central. Mesmo se tratando de um simples diagrama já é possivel perceber que o carâter do centro público de Howard é bem distinto daquele que Sitte e Unwin adotaram para o centro das cidades. Howard propōe "seis magnfficos passeios de 120 pés (aproximadamente $40 \mathrm{~m}$ ) de largura, cada um deles dividindo a cidade em seis partes ou distritos iguais. No centro há um espaço circular, que cobre uns cinco acres e meio (aproximadamente $-22.000 \mathrm{~m}^{2}$ ) coberto por um formoso e bem regado jardim; rodeando este jardim estão os grandes ediffcios públicos ... situados todos eles em terrenos espaçosos e independentes".

Uma outra vertente do urbanismo, partindo de outras premissas ${ }^{2}$ propōe modelos que rompem radicalmente com as formas e os usos dos espaços urbanos existentes ou concebidos até então. Convencidos de que uma nova era havia chegado e que as propostas de transformaçōes urbanas não faziam face aos novos desafios e nem exploravam o fabuloso potencial técnico disponivel, os urbanistas da chamada corrente progressista dedicaram-se a projetar a cidade do futuro. A "Ville Radieuse" de Le Corbusier, idealizada na década de 30, representa bem o pensamento dos arquitetos e urbanistas empenhados neste compromisso ${ }^{3}$. Num hipotético diálogo com os técnicos da Prefeitura de Paris, assim se exprime Le Corbusier: “... Demolir o centro. É o que nós propomos ... Os senhores concordam, então os senhores concordaml Não há outro jeito. Mas nós, nós o faremos por partes, racionalmente, com bom senso. Ali nós criaremos a "Ville Radieuse". E ali, onde os senhores semeariam cenouras, nós propomos densidades de 3.200 habitantes por hectare na área central e de 1.000 na área residencial. Nós valorizamos formidavelmente o solo urbano".

A idéia de centro se mantém mas seu significado e sua morfologia são totalmente diversos dos centros anteriores. A rua como espaço corredor para onde se abrem as casas, as lojas e onde circulam pedestres e velculos é eliminada: "As ruas não dāo certo. As ruas são um conceito velho. As ruas não devem existir; é preciso criar qualquer coisa que substitua as ruas".

As estaçōes deixam de ter conteúdo simbólico e passam a ser consideradas como elementos estritamente funcionais: "(...) a cada $400 \mathrm{~m}$ os trens páram entre dois aranha-céus. A malha se interrompe ali; o espaço é ocupado por uma estação abrigo. Isto funciona”. E quando a estação central: “... não é um monumento. É um utensilio. Os monumentos estāo em outros lugares".

As praças como local de domf́nio do pedestre, espaço privilegiado para a manifestação da vida urbana, para o encontro ou o descanso, não têm mais sentido pois todo o solo é dedicado ao pedestre: "No plano de "Ville Radieuse" eu simplesmente propus entregar a totalidade do chão da cidade ao pedestre, a t-o-t-a-l-i-d-a-d-e do chão, como um campo raso. E desenhei as autopistas no ar, cinco metros acima do chão".

Os aranha-céus da área central têm sua forma (em cruz) e sua altura (220 m) definidas. A circulação está estudada detalhadamente, com dez tipos de cruzamentos. Mas não há nenhuma referência às condiçōes de localização ou desenho de uma possivel praça. Não seria mesmo o caso; a "praça" pode estar em qualquer ponto do imenso plano dedicado aos pedestres.

O espaço livre público caracteristicamente urbano (espaço de contato, lugar de simultaneidade, diversidade e densidade de acontecimentos) entra num impasse enquanto objeto de estudo e propostas urbanisticas. De um lado o urbanismo progressista que Ihe nega a materialidade especffica, diluindo-o em grandes superffcies com muito verde, luz e ar ou segregando-o pela classificação radical das funçōes. De outro a alternativa culturalista proclamando o retorno às formas do passado como se magicamente, a partir das formas, a vida ressurgisse nas praças ${ }^{4}$.
(2) Os principlos que nortearam o -urbanismo progressista" estăo sintetlzados na Carta de Atenas.

(3) "Apesar das sltuaçס̋es polfticas e economicas multo diversas, uma imagem análoga da cldade futura $\theta$ extrafda das pesquisas empreendldas quase simultaneamente, nos Palses Baixos por $\mathrm{J}$. P. Oud, G. Rietveld $\theta$ C. Van Eesterem, na Alemanha pela Bauhaus de Gropius, na Rússia pelos construtlvistas, na França por A. Ozenfat $\theta$ Le Corbusier. CHOAY, F, O Urbanismo, op. clt.

(4) É necessário ressalvar que Sitte, mesmo proclamando a excelencia do espaço urbano medle val, năo delxa de lançar dávidas sobre a "natura Ildade artificial presente nas tentativas de Inventar, planejar e construlr as mesmas casualldades que a historla produziu ao longo dos séculos" SITTE, C. op.clt. 
A hegemonia que o urbanismo racionalista exerceu, tanto na produção de idéias como nas realizaçőes concretas até a década de 60 , afastou de cena as discussōes sobre os espaços livres públicos centrais ou subcentrais. $O$ interesse pelo assunto voltará em decorrência de uma crftica mais abrangente que se fará aos modelos de urbanismo, já apoiada na avaliação das experiências efetuadas.

Em artigo publicado em 1960 na revista Landscape, Lewis Munford observa que: “... a função social dos espaços livres na cidade é a de reunir as pessoas. As experiências de Unwin em Hampstead (Garden Suburb) em 1908 e de Wright e Stein em Radburn, em 1928, demonstraram que o contato entre as pessoas é favorecido quando os espaços públicos e privados são projetados simultaneamente. Infelizmente o congestionamento da cidade provocou uma reação que supervalorizou um ideal meramente quantitativo de espaços livres. "... Não devemos nos iludir com a amplidão espacial que se pode obter concentrando as famlias em ediffcios de quinze ou vinte andares. Um espaço livre visual e genérico não significa um espaço livre adequado para recreação ou para jardins particulares, por exemplo".

A defesa dos espaços de contato, num ambiente com fortes conotaçōes urbanas, por oposição aos espaços livres genéricos e indiferenciados, também será feita por Jane Jacobs no livro "Morte e vida das grandes cidades americanas", publicado em 1961. Associa o êxito ou fracasso dos espaços livres públicos às caracterlsticas do ambiente urbano em que se inserem e ao modo como se inserem neste ambiente.

Para argumentar que os espaços livres não são valores em si, mas altamente dependentes dos contextos, toma como exemplo as diferenças que resultaram em cada uma das quatros praças (ou parques de bairro) do plano de Willian Penn para Philadelphia, em fins do século XVII. Eram quatro espaços originalmente iguais em termos de destinação e equivalentes enquanto localização, situados simetricamente em relação aos eixos organizadores do plano. Uma das praças, a Rittenhouse Square, tornou-se o centro de um conjunto de bairros diversificados, é animada durante o dia todo por diferentes tipos de usuários: crianças, donas-de-casa, trabalhadores, estudantes, que a freqüentam em função de seus ritmos cotidianos. Jâ a Franklin Square, com dimensōes e formato iguais aos de Rittenhouse, por estar situada num setor menos dinåmico da cidade atrai usuários "pobres e esquálidos", é uma praça sem vida. Menos feliz ainda foi a sorte da Washingtohn Square situada numa zona especializada em agéncias de despacho, companhias de seguro, publicidade e oficinas: transformou-se um local de criminalidade, evitado mesmo na hora do almoço pelos empregados das oficinas próximas. Por fim a quarta praça de Willian Penn ficou reduzida a uma rotatória de trǻfego, a Logam Circle, num setor da cidade caracterizado pela concentração de "centros culturais". Jacobs conclui que a diversidade da estrutura urbana das imediaçōes é condição indispensável para a animação das praças.

O urbano como lugar do encontro, da simultaneidade, como "teatro espontâneo" é também reabilitado por Henri Lefêbvre em "O Direito à Cidade" escrito em 1967. O modo de vida urbano é esboçado como uma utopia (porém vinculada ao real e ao possível) que tem seu próprio tipo de centralidade: a centralidade lúdica ${ }^{5}$ que, por sua vez, não se vincula a nenhuma estrutura fixa; a nenhum espaço estável.

¿ Ainda que não submetido à fixação no espaço persiste em Lefébvre a idéia de centro urbano: "o centro urbano traz, para as pessoas da cidade, o movimento, o imprevisto, o possivel e os encontros". Não se deve tentar transpor a centralidade enunciada por Llefébvre a este ou àquele tipo de espaço público. Seria uma redução empobrecedora, antes mesmo impossivel de ser feita, pois o enfoque de Lefèbvre é prospectivo e não operativo. No entanto ela não descarta a necessidade de "projetos urbanisticos bem desenvolvidos, compreendendo 'modelos', formas de espaços e de tempos urbanos (vinculados) a um programa politico de reforma urbana" e, portanto, da formulação concreta dos espaços destes projetos. Não se deteve porém (o que é muito compreensível pela abordagem que se propo̊s) na consideração das qualidades materiais destes espaços. O máximo que sugere como contornos da nova situação proposta é se imaginar "a inversão da situação atual", inversão esta que não reconduz certamente a um racio- 
nalismo elementar (isto parece bem claro quando afirma que: "o espaço lúdico coexistiu e coexiste ainda com espaços de trocas e de circulação, com o espaço polltico, com o espaço cultural. Os projetos que perdem esses espaços qualitativos e diferenciados no seio de um 'espaço social' quantificado, regulado apenas por contagens e pela contabilidade, esses projetos se baseiam numa esquizofrenia que se cobre com os véus do rigor da cientificidade, da racionalidade") nem a um culturalismo primário ("o direito â cidade não pode ser concebido como um simples direito de visita ou de retorno às cidades tradicionais. Só pode ser formulado como direito à vida urbana transformada, renovada". E ainda, "Po̊r a arte ao serviço do urbano não significa de modo algum enfeitar o espaço urbano com objetos de arte. Esta paródia do possivel denuncia a si mesma como caricatural").

A cidade ideal de Lefẻbvre comportaria a "obsolescência do espaço: transformação acelerada das moradias, dos locais, dos espaços preparados. Seria a cidade efêmera, perpétua obra dos habitantes, eles mesmos móveis e mobilizados para/por essa obra" 6 .

De que modo estas consideraçōes de Lefèbvre se situam nos limites do assunto aqui tratado? Em primeiro lugar pela afirmação de uma centralidade que se expressa no nfvel prático sensivel em "locais de encontro e de trocas ... separados do valor de troca". Seguramente não está se referindo a shopping-centers, freqüentemente mencionados como a versão mais recente do espaço público. Em segundo lugar a heterogeneidade $e$ a simultaneidade como condiçōes necessárias à realização do "teatro espontâneo": 0 movimento, o imprevisto, o possivel e os encontros. Estas condiçőes têm ótimas possibilidades de realização nos espaços livres públicos urbanos (embora não exclusivamente neles) na medida em que permeiem funções urbanas diversificadas e estejam em estreito contato com elas. Em terceiro lugar a prevalência da obra sobre o produto $e$ do tempo sobre o espaço. Ao projeto como produto acabado antepõe o processo (a cidade como "perpétua obra dos habitantes").

Priorizando o processo (a dinâmica do tempo) e considerando a cidade como perpétua obra dos seus habitantes, reduz a importância do produto acabado (a inércia das formas do espaço) e pode levar ao questionamento do projeto com "direitos autorais". No entanto o tempo sempre vem se realizar num espaço, mesmo que efêmero. $E$ o espaço, mesmo que pensado para ser efêmero, tem sua concretitude (pelo menos durante um certo tempo). A subordinação do espaço ao tempo significaria obrigatoriamente a obsolescência expressa do espaço? A flexibilidade do espaço deveria ser entendida de modo literal, levando à proposição de estruturas "desmontáveis"? Dar prioridade ao tempo também pode ser entendido no sentido de superar a rigidez dos espaços especializados, relacionados a um só tempo; no sentido de admitir que num mesmo espaço muitos tempos possam se realizar, não só sucessivamente, mas também simultaneamente. Os espaços (e entre eles os livres-públicos-coletivos-urbanos) deverão estar sempre disponfveis para serem apropriados em qualquer tempo. Para que isto aconteça, ao menos no referente aos espaços livres públicos aqui tratados, seriam necessárias algumas condiçōes minimas de ordem locacional, funcional e morfologica (além das condiçōes relacionadas à prática social): acessibilidade fácil (imediata mesmo), diversidade de funçōes nos espaços contlguos, dimensōes adequadas.

Que desenho terão estes espaços? Ainda que se considere a efemeridade do espaço e que o projeto deixe de ser atribuiçăo exclusiva de especialistas, haverá um desenho para atender a determinados objetivos, expressar determinadas indicaçőes que se materializam em formas organizadas, segundo uma linguagem erudita ou vernacular.

Uma abordagem direta desta questão é realizada por Paul Zucker no livro Town and Square (1959), num estudo aprofundado da morfologia das praças consideradas em sua totalidade tridimensional.

Zucker não se limita à descrição e à constatação dos tipos de praças no decorrer da História. Vai além ao sustentar que existem arquétipos tridimensionais de praças que se tornaram autônomos, isto $\hat{k}$, desvinculados das motivaçōes originais responsáveis pelo seu aparecimento e desenvolvimento. Assim é possivel reencontrar a estrutura
(6) Numa pequena passagem Lefebvre delxa entrever como a prática (o fazer a obra) pode vel cular a poesla, usando os espaços llvres como exemplo, o que vem multo a calhar: "Nåo esque çamos que os jardins, os parques e palsagens if zeram parte da vida urbana tanto quanto as belas artes. E que a palsagem ao redor das cldades fol obra dessas cldades... Delxando a representaçăo, o ornamento, a decoraçáo, a arte pode se tornar praxls e poeslas em escala social: a arte de viver na cldade como obra de arte". LEFÉBVRE, H. op. clt 
espacial da Ágora pós Hipodâmica em pleno século XIII nas fortificaçర̋es francesas ou a organização axial do Fórum Imperial de Roma na seqũência de praças em Nancy, no século XVIII. Năo que Zucker desconsidere as mudanças contlnuas a que uma praça está sujeita em funçăo de variáveis sócio-econômicas e estillsticas, mas observa que "diferenças morfoløgicas de sucessivos estilos săo de menor importância. Eles se refletem mais nos ediffcios lindeiros do que na forma intrinseca da praça propriamente dita".

São cinco os arquétipos considerados por Zucker:

1 - Praça fechada: é a concepçåo comum de praça como espaço complementamente cercado por edificaçర̃es, apenas interrompido pelas ruas que Ihe dăo acesso. Neste tipo de praça os elementos básicos para a percepção visual do espaço são: a forma da planta (plano horizontal do piso, em geral uma figura geométrica regular), a relaçăo entre as dimensठ̋es horizontais da planta e verticais dos ediffcios que a envolvem, a continuidade construtiva e uma relativa homogeneidade tipológica das construçðes, elementos estes que conferem a este arquétipo a qualidade de um espaço em equilbrio estático.

2 - Praça dominada: organizada em função de um elemento (ou grupo de elementos) que determina as principais relaçōes espaciais. Este elemento dominante pode ser um ediffcio (igreja, teatro, estação ...), um objeto (uma fonte, um portal ...), um eixo (caso comum às praças associadas a pontes), ou mesmo uma paisagem (praça com um dos lados abertos para o horizonte como a Praça dos Três Poderes em Brasnlia, a Piazzetta em Veneza, a Praça do Comércio em Lisboa). Em qualquer caso, a praça dominada apresenta uma organizaçăo espacial dinåmica devida à atração exercida pelo elemento dominante sobre a percepção e o movimento do observador.

3 - Praça nuclear: a sensação espacial de praça é obtida pela presença de um núcleo (monumento, obelisco, fonte ...) "suficientemente forte para carregar o espaço em torno com uma tensão que confere unidade ao conjunto". Mesmo que os ediffcios adjacentes tenham formas, dimensőes e implantaçőes variadas a unidade espacial é garantida pelo elemento nuclear.

Naturalmente o efeito do núcleo é limitado, restringindo-se portanto a praças relativamente pequenas, ou pelo menos, proporcionais no poder de atraçăo do núcleo.

4 - Praças agrupadas: trata-se de sequeências de praças em que, não obstante cada uma ter sua própria individualidade, a noção de conjunto é garantida. Esta seqũência é composta por praças de diferentes formas e escalas, que se associam ou por intermédio de um eixo comum, ou de eixos ortogonais, ou por gravitarem em torno de um ediff cio dominante. Neste arquétipo, as dimensỏes relativas de cada praça e o modo pelo qual se dá a conexão entre elas desempenham um papel importante na percepção do conjunto.

5 - Praças amorfas: apesar de serem consideradas praças para efeito de cadastramento de logradouros públicos, são destitufdas das qualidades espaciais que caracterizam os tipos anteriormente mencionados. A praça amorfa tem em geral planta com forma indefinida, ausência de unidade e desproporçōes de escala. Pode ocorrer de a planta apresentar forma geométrica regular e mesmo assim resultar um espaço amorfo, pelo fato das relaçőes de proporção entre a praça e os ediffcios circundantes serem inadequadas. Ainda pode acontecer o caso em que o possivel efeito agregador de um elemento nuclear ser neutralizado pela excessiva disparidade entre os edifficios em torno da praça.

O maior interesse do trabalho de Zucker não está na classificação em si, mas em permitir a conclusão de que existem arquétipos de praças ou seja, unidades morfológicas autônomas, superando com esta constatação tanto as diferenças entre os modelos culturalista e progressista, como liberando o que se poderia chamar de arcabouço, ou estrutura espacial da praça, de variáveis estillsticas.

Os estudos morfológicos e morfométricos são contribuiçōes efetivas para a análise formal e para o projeto das praças. Estão todos, no entanto, apoiados nos pressupostos de coerência arquitetônica dos ediffcios que formam o arcabouço da praça, na defi- 
nição precisa dos limites do espaço ou na valorização das qualidades de "fechamento" e de "escala" que dal decorrem. Todos implicam na vinculação estrutural praça-ediffcios como condição para um bom resultado, condição comum nas cidades medievais $e$ na produção urbanistica até o século XVIII na Europa, talvez ainda desejável, mas com minimas possibilidades de se realizar hoje.

$\mathrm{Na}$ mesma linha da unidade indissolúvel praça-ediffcio, e ainda neste perlodo dos anos 60 e 70, situam-se as propostas de Bob Krier em seus projetos de Stuttgart.

Mas nas novas intervenções urbanas levadas a efeito em áreas de urbanização já consolidadas, esta unidade não se verifica.

Já não se pretende (ou não se pode pretender) formar o arcabouço da praça pelo controle da tipologia da arquitetura que a envolve.

Seja por questōes de custo (intervir no espaço edificado é, de modo geral, mais caro de que intervir estritamente no espaço livre), seja porque a praça tenha deixado de ocupar - lugar prioritário na organização do espaço urbano, o fato é que construir, demolir ou reformar ediffcios com o pretexto de formar o arcabouço adequado para uma praça, é uma possibilidade muito remota. No geral o arcabouço e mesmo o traçado viário já vếm dados e estão longe de oferecer condiçōes satisfatórias. No entanto, as oportunidades de atuação nos espaços livres públicos não podem ficar na dependência de condiçōes ideais. Neste sentido o exemplo recente de Barcelona apresenta um grande interesse.

A partir da revisão do Plano Geral Metropolitano de Barcelona (aprovado em 1976) foram projetadas cento e sessenta operaçōes urbanas, em grande parte já realizadas. Estas realizaçōes, que datam do inf́cio dos anos 80 , foram efetuadas pela Área de Urbanismo e Obras Públicas de Barcelona, sob a coordenação de Oriol Bohigas, com a colaboração da Faculdade de Arquitetura e em sintonia com as expectativas da população diretamente atingidas pelas intervençőes.

O interesse no caso de Barcelona está na intenção de atuar diretamente no espaço público visando "converté-lo num equipamento de qualidade, e num ponto gerador de transformações espontâneas" 7. A revisão do Plano Geral Metropolitano se fez a partir de uma discussão, tamberm bastante oportuna, enfocando dois assuntos importantes: um deles trata da oposição entre plano e projeto, o outro de "o conceito de cidade como um sistema ideal unitário e o conceito de cidade como soma conflitante de fragmentos reais". O método adotado na revisão do Plano, propõe que se dê ao plano conteúdos projetuais, deixando de considerá-lo simplesmente como um plano geral distante das configuraçōes concretas existentes ou por realizar. E opta claramente por "entender a cidade mais como uma soma de realidade do que como um modelo de sistematização e, portanto, de utopia regressiva".

Coerentemente com os princlpios assumidos procurar-se-á ver a cidade a partir do bairro e dar prioridades "às pequenas e cotidianas carências da realidade". As prioridades foram estabelecidas segundo três critérios: 1) atendimento a bairros degradados; 2) intervençōes em áreas que pudessem dar um retorno mais imediato aos investimentos; 3) atuação em espaços que tenham ou possam vir a ter uma importância simbólica coletiva. Vários espaços referentes a este último critério são trechos de ruas, praças e parques de pequenas dimensōes em que não foi preciso lançar mão de desapropriaçōes, nem investir grandes recursos. O exemplo mais conveniente é o da "Plaça dels Paisos Catalans" ou Praça da Estação de Sants ${ }^{8}$, a principal estação ferroviária de Barcelona e conectada ao Metrô, pela semelhança de condiçōes com os espaços públicos associados às nossas estaçōes de Metrô.

A área da praça era uma simples sobra do sistema viário, amorfa e sem qualquer previsão funcional. $O$ espaço envoltório é indefinido, os ediffcíos são distantes, não têm coerência arquitetônica e mesmo o ediffcio da estação, que poderia de algum modo delimitar o espaço, está separado da área destinada à praça por um estacionamento ao ar livre que deveria ser mantido. Outra limitação agravante: a área da praça é a laje de cobertura da ferrovia, não permitindo - por não ter sido dimensionada para isto - a construção de ediffcios nem a implantação de massas vegetais de porte. A despeito desta
(7) O projeto da Praça da Estaçăo Sants é de autorla de Héllo PInón. Albert Vílaplana e Enric Miralles. Relatos, anállses e comentárlos sobre o projeto podem ser encontrados em BOHIGAS, Orlol. Reconstrucclo de Barcelona", em "Spazio e Societa", $n^{2} 24,1983$ e em "The Architecture Review", v. CLXXV, n 1048, June 1984.

(8) Esta área corresponde à praça em frente à estaçăo já executada. A área atrás da estaçăo, com aproximadamete $8.000 \mathrm{~m}^{2}$, deve ter um tratamento simllar à anterlor, mas sua execuçâo năo entrou na primelra fase do programa. 
Foto 1

Praça da estação Sants Maquete

\section{Foto 2}

Praça da estação Sants

Relaçōes com a paisagem circundante

\section{Foto 3}

Praça da estação Sants

Relaçōes com a paisagem circundante
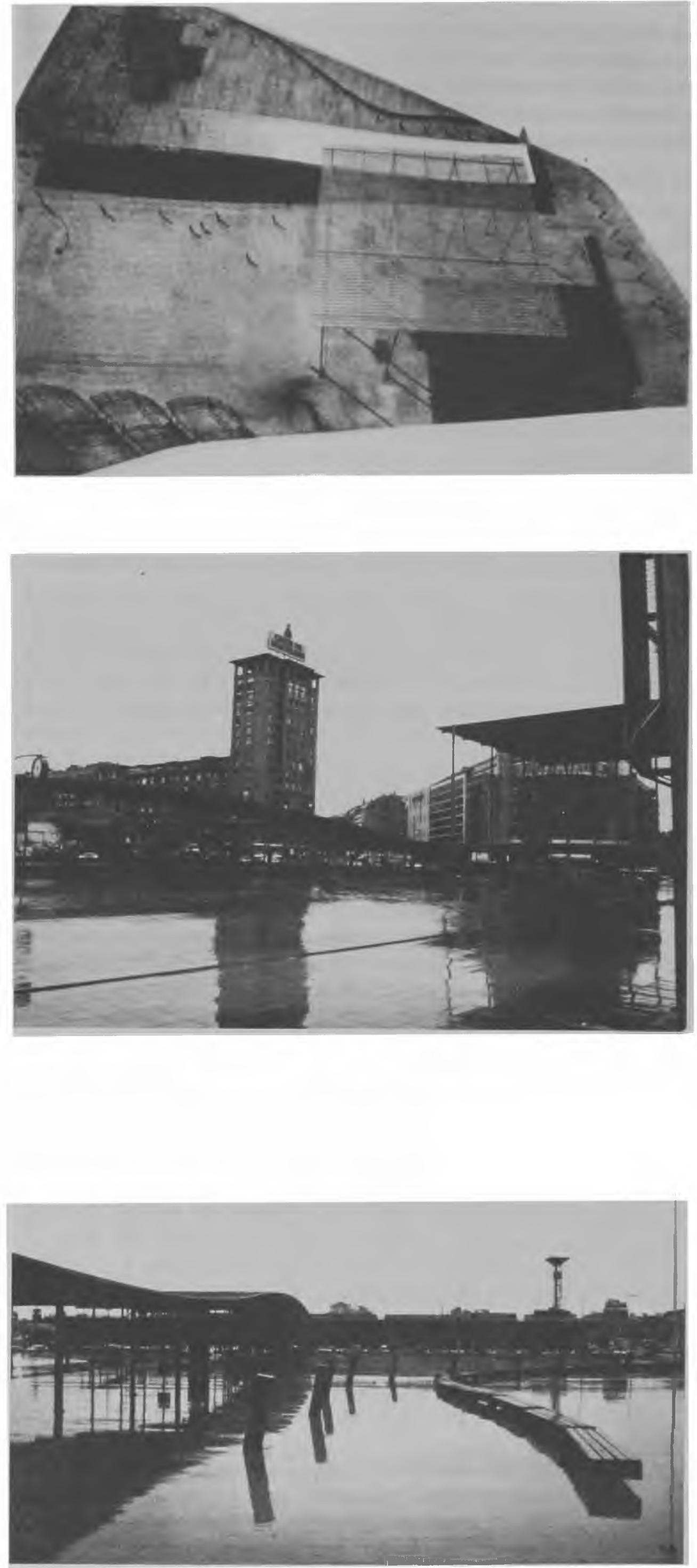
situação, caracterizada pela total ausência de intenção formal e funcional do espaço público (em parte devida à distância que os planos mantêm em relação aos projetos) ao se proceder à revisão do Plano Geral Metropolitano houve a sensibilidade suficiente para perceber a importância que este espaço, de aproximadamente $12.000 \mathrm{~m}^{2} 9$, poderia ter como núcleo significativo de um novo centro urbano.

A praça da estação foi, portanto, concebida como espaço central, aberto à multiplicidade de usos e de tipos de usuários e possuidor de uma dimensão simbólica. $O$ partido adotado não se baseou numa ambiciosa e pouco factlvel intervenção na "arquitetura" existente em torno da praça, nem na formação de um arcabouço próprio que garantisse um espaço livre com maior controle formal. Assumiu as condiçōes da realidade espacial do lugar, buscou uma consistência arquitetônica própria e ao mesmo tempo aberta para a descontrolada paisagem existente. Para tanto foram utilizadas estruturas metálicas com cobertura translúcida que tomam as formas de um pálio, de marquises e de biombos.

Os elementos estruturadores do espaço da praça são o pálio (cobertura horizontal de $30 \times 30$ m sustentada por pilares de metal de $15 \mathrm{~m}$ de altura) e a marquise linear (um retângulo alongado de $10 \mathrm{~m}$ de largura por $100 \mathrm{~m}$ de comprimento, mais baixo que o pálio, e com amplas ondulaçōes na cobertura). No estacionamento ao ar livre, entre a praça e a estação, as estruturas metálicas foram dispostas em forma de marquises inclinadas "para corrigir a pobreza de sua composição (da estação)" ${ }^{10}$ desempenhando ao mesmo tempo o papel de elemento de ligação e de linha de partida para a composição espacial. Segundo Bohigas estes elementos - o pálio, a marquise de cobertura ondulada e as marquises inclinadas - "são um sistema tão potente que consegue reduzir o caos circundante a meras anedotas alheias à realidade da praça". Um pequeno desnivel de três degraus atravessa a praça longitudinalmente. $O$ desenho do piso acompanha este eixo discreto formado pelo desnlvel, consistindo na marcação sutil de duas direções (perpendicular e paralela ao eixo) dadas pelo alinhamento de placas de granito. Sobre os dois planos que o desnivel define, e dominados respectivamente pela marquise linear e o pálio, estāo dispostos elementos que, embora complementares, sāo essenciais para a caracterização da praça: a parede com janela (enquadramento crítico da paisagem circundante?) no final da marquise, a série de repuxos d’ågua, o relógio, 0 traço sinuoso formado pelos bancos de madeira e pelas luminárias ligeiramente inclinadas, as linhas de esferas apoiadas sobre o piso, os biombos de estruturas metálicas para trepadeiras (único elemento vegetal utilizado) na transiçāo para o Parque da Espanha Industrial, este contando com presença mais significativa de vegetação. A parcimo̊nia e a precisāo na disposiçāo dos elementos permitem a alguns classificar este projeto como minimalista, enquanto outros os associam a algumas proposiçōes do dadalsmo, na medida em que o potencial lúdico do espaço e a recusa em isolá-lo das interferências do contexto, liberando-o da redoma que envolve as obras de arte, realizam a proposta dadalsta de substituir a obra de arte pelo ato estético.

De qualquer modo, mais importante que as classificações sāo as possibilidades que as recentes intervençōes em Barcelona e em particular o caso apresentado da Praça da Estação de Sants, abrem para o projeto dos espaços livres públicos tanto pela reafirmação e renovação dos seus conteúdos, como pela atualização das questôes de linguagem e das relaçōes morfológicas com o espaço envoltório.

Jå se questionou e criticou em várias ocasiōes a atuação do Metrô de São Paulo por ter exorbitado de suas funçōes ao criar praças junto às suas estaçōes. Poderia ter se limitado à correta inserçāo dos acessos, sem maiores pretensōes. A crftica é procedente apenas em parte. Não se deve deixar de considerar que as estaçōes podem adquirir um significado mais abrangente, mais rico do que um mero ponto de parada num sistema de transporte, sobretudo em áreas pobres em referências espaciais. $O$ espaço livre que Ihes corresponde - a praça da estaçāo - acaba por adquirir parte deste significado. É espaço de transiçăo: transição flsica e transição de conteưdos. É espaço de fluxo mas é também espaço que introduz ao lugar.
(9) "O no deste novo centro ocidental de Barcelona $\hat{\theta}$ a praça da estaçåo, através da qual ressurge a boa tradiçáo centralizadora dos terminals de trem, tâo arraigada nas grandes cidades ... como nos pequenos povoados $\theta$ nas capltais de provincla onde a estaçāo continua sendo um ponto de encontro. Ao lado deste espace seco e concen trador da Estaçăo de Sants eståo sendo construf dos diversos parques, cuja vegetação se abrirá as microcircunstanclas dos bairros BOHIGAS, Orlol. "Reconstrucclo de Barcelona". op. cit.

(10) Peter Buchanan em artigo na revista The Architectural Review, v, CLXXV, $n^{2}$ 1048, June 1984, afirma que a praca \& "descomprometlda mente minimalista $\theta$ moderna". Bohigas em "Ro construcclo de Barcelona" faz o segulnte comentário: "O desenho de cada elemento e a estrutura do espaço correspondem a uma elaboraçấo inte ligente de signos figurativos orlginados nas van guardas, Sobre a retangularldade das marquises, da pergula (marquise ondulada) o do pallo se ar. ticulam itinerários desconjuntados - as lumináticulam Itinerários desconjuntados - as luminá-
rias, os bancos, os repuxos - $\theta$ todo um acámulo de interferênclas gráficas através da transparêncla direcional das coberturas de metal ondulado, que permitem ler a composiçấo segundo as cha ves interpretativas de um certo setor da pintura moderna.... Seria exagerado - e injusto pelas desconsideraçóes cronológlcas - dizer que a Praça da Estaçāo de Sants ó uma arquiltetura Dadá. No entanto nâo seria multo diffcil encontrar nela referenclas a algumas afirmaçoes dadalstas a arte 'amorta' que é unicamente gesto, a obra de arte como uma máquina de "funcionamento sim bólico", a renáncla as técnicas e aos materlals especificamente artistlicos, 0 ato estético em substitulçăo à obra de arte $\theta$, talvez, a afirmaçăo do readymade dlante do desenho industrlal". 
Considere-se ainda que o Metrô, enquanto transporte rápido de massa, aumenta consideravelmente a acessibilidade dos lugares por ele servidos $e$, ao favorecer o lugar, possibilita a diversidade de usos e de usuários. O Metrô é também um equipamento ligado ao cotidiano das pessoas, ao lado prosaico de suas vidas. Todo este potencial a presença diária, o envolvimento de um grande número de pessoas, a acessibilidade, a possibilidade de unir o heterogêneo e o simultâneo - merece ser aproveitado e expresso nos espaços livres públicos associados às estaçōes. Estes podem vir a ser lugares em que se realizam tanto o cotidiano como a Festa (Lefèbvre), o mais permanente e o mais efêmero.

Acreditamos que estas obeservações justificam a valorização do conteúdo destes espaços, aspecto quase sempre negligenciado nos projetos e, no entanto, possivel de ser atendido mesmo diante das condiçōes mais limitadas em que se dá a produção dos espaços livres públicos hoje em dia.

\section{Referências Bibliográficas}

BARCELONA. Ajuntament de Barcelona. Àrea d'Urbanisme Obres Pùbliques. Barcelona-Espais i Escultures (1982-1986). Barcelona, 1987.

BOHIGAS, Oriol. Reconstrucció de Barcelona. Barcelona: Edicions 62.1985.

. Spazi per la gente. Spazio e Societá. $n$ ㄴ24, dez. 1983.

BRUEGMANN, Robert. Two post modernist visions of urban design. Landscape Architecture, feb. 1982.

CHOAY, Françoise. O Urbanismo. São Paulo: Perspectiva, 1979.

DE CARLO, Giancarlo. La crisi della città e il caso di Barcelona. Spazio e Societa, n² 24, dez. 1983.

HOWARD, Ebenezer. Garden cities of tomorrow. Londpn: Faber \& Faber, 1946.

JACOBS, Jane. Muerte y vida de las grandes ciudades. Madrid: Peninsula, 1967.

JEANNERET, Gris. La Ville Radieuse. Paris: Editons Vicent-Fréal, 1933, reimpression en 1964.

KRIER, Rob. EI Espacio Urbano. Proyectos de Stuttgart, Barcelona: Gili, 1981.

LE CORBUSIER, La ville radieuse. Paris: Vincent Fréal, 1933.

LEFĖBVRE, Henri. O Direito à Cidade. São Paulo: Documentos, 1969.

MUNFORD, Lewis. The social function of open spaces. Berkeley, Califómia: Landscape, v. 10, n. 2, 1960-1961.

SITTE, Camillo. City planning according to artistic principles. New York: Rondon House, 1965.

UNWIN, Raymond. Town planning in practice: an introduction to the art of designig, cities and suburbs. London: Unwin, 1913.

ZUCKER, Paul. Town and square. New York: Columbia University Press, 1959. 